\title{
COMPARATIVE STUDY OF THE POWER OUTPUT OF A MOBILE PV PANEL AND A FIXED PV PANEL
}

\author{
Sène Diatta *, Sarr Adama, Ndiaye Mouhamadou Falilou \\ École Supérieur Polytechnique, Université Cheikh Anta Diop, BP 5085, Dakar, Sénnégal \\ *diattasene88@gmail.com
}

\section{INFOS SUR L'A R T I C L E}

\section{Historique de l'article:}

Reçu le : 24 novembre 2020

Réçu en format revisé le : 09 février 2021

Accepté le : 11 février 2021

\author{
Mots-Clés: Panneau PV mobile, Panneau \\ $P V$ fixe, Centrale PV solaire, Suiveur
}

solaire, Production

Keywords : Mobile PV Panel, Fixed PV

Panel, Solar PV Power Plant, Solar

Tracker, Production

\section{RE S U M E}

Avec le coût élevé de l'électricité, les centrales électriques ne sont plus rentables et les énergies renouvelables deviennent un domaine d'étude privilégié. Cela justifie qu'au Sénégal, on constate de plus en plus la création de centrales photovoltaïques et de petites installations domestiques afin de satisfaire les besoins en électricité. Cependant, nous constatons une limitation des terrains pour répondre à nos besoins pour l'installation de ces centrales solaires $\mathrm{PV}$. La question est de voir avec le peu d'espace dont nous disposons comment optimiser au maximum la quantité d'énergie pour répondre à la demande ? Comme l'inclinaison des panneaux photovoltaïques est souvent fixe et que cela ne donne pas toujours une énergie optimale, nous avons pensé aux suiveurs solaires. L'objectif de ce travail est de comparer la puissance de sortie des deux panneaux PV, avec les mêmes caractéristiques et dans les mêmes conditions environnementales. Pour ce faire, nous procédons en calculant la puissance maximale disponible à la sortie d'un panneau photovoltaïque. Cela consiste à rechercher les modèles mathématiques qui permettent de calculer cette puissance. Pour choisir le modèle le plus proche de la puissance caractéristique donnée par le fabricant du panneau PV dans les conditions de test, nous avons écrit un programme sous l'environnement Matlab, les résultats de ce script distinguent ce modèle. Les caractéristiques du panneau PV choisi sont appliquées dans chaque cas d'installation photovoltaïque. Ces résultats ont montré que la production du panneau PV mobile est plus importante que celle du panneau PV fixe. Nous avons constaté que la puissance électrique du panneau $\mathrm{PV}$ mobile produit plus de 10 à $38 \%$ supérieure à celle du panneau $\mathrm{PV}$ fixe selon le jour du mois considéré.

\section{ABSTRACT}

With the high cost of electricity, power plant are no longer profitable and renewable energies are becoming a preferred field of study. This justifies that in Senegal, we notice more and more the creation of photovoltaic power plants and small domestic installations in order to satisfy electricity needs. However, we are seeing a limitation of land to meet our needs for the installation of these solar power plants. The question is to see with the little space we have how to optimize the maximum amount of energy to meet the demand? Since the inclination of the PV panels is often fixed and this does not always give optimal energy, we thought of solar trackers. The objective of this work is to compare the power output of the two PV panels, with the same characteristics and under the same environmental conditions. To do this, we proceed by calculating the maximum power available at the output of a photovoltaic PV panel. This consists of looking for mathematical models that calculate this power. To choose the model closest to the characteristic power given by the PV panel manufacturer in the test conditions, we have written a program under the Matlab environment, the results of this script distinguish this model. The characteristics of the chosen PV panel are applied in each case of photovoltaic installation. These results showed that the production of the mobile PV panel is more important than that of the fixed PV panel. We found that the power output of the mobile PV panel produces more than 10 to $38 \%$ higher than that of the fixed PV panel depending on the day of the month considered. 


\section{INTRODUCTION}

Energy is an indispensable factor in life. We can mention fossil fuels and renewable energies. But without doubt we note constraints related to fossil energies. Thus, the main impacts on the environment due to our consumption of fossil fuels increase local pollution, which leads to a global disturbance of atmospheric phenomena and an increase in waste, especially nuclear waste (Bidart and Dubois 2003). In addition, with the depletion of fossil fuel reserves, economic crises due to soaring oil prices, accidents at nuclear power plants such as Three Mile Island (USA, 2079) or Chernobyl (USSR, 2086), the general public's interest in renewable energies is growing (Gueye et al. 2015). However, photovoltaic energy has shown a growing interest in the last ten years, unlike fossil fuels (Ndiaye et al., 2018).

This makes photovoltaic solar energy one of the most promising types of renewable energies (Aidara, Ndiaye, and Nkounga, 2018). It is in this context that Senegal has embarked on this race for photovoltaic solar power plants. These solar power plants are often with fixed orientation. Thus, we note constraints related to these types of installations, namely on the production which is not optimal and on the land space which is too limited, for example in the Dakar region. This leads us to wonder with the limited space available how to optimize the energy production of the photovoltaic field. To do so, we will compare the power output of a solar tracking PV panel with another PV panel with fixed orientation. That is to say, what will be the variation of the power output of the mobile PV panel compared to the fixed panel? Part 1 describes the equipment and methods. Part 2 presents the results and discussion and Part 3 concludes this work.

\section{MATERIALS AND METHODS}

Several mathematical models allow to calculate the power available at the output of the terminal of a photovoltaic panel. However, we will use four models to compare their results with the reference power of the panel given by the PV panel manufacturer.

\subsection{Model 1}

This model is given by the equation (1) (Cisse and Ndiaye 2018):

$$
\begin{array}{r}
P_{1}=\left[V_{m p}+\mu_{v}\left(T_{c}-T_{0}\right)\right]\left[\frac { G } { G _ { 0 } } \left(I_{m p}\right.\right. \\
\left.\left.+\mu_{I}\left(T_{c}-T_{0}\right)\right)\right]
\end{array}
$$

With

$$
\begin{aligned}
& V=\left[V_{m p}+\mu_{v}\left(T_{c}-T_{0}\right)\right] \\
& I=\frac{G}{G_{0}}\left(I_{m p}+\mu_{I}\left(T_{c}-T_{0}\right)\right) \\
& T_{c}=T_{a}+\frac{G}{800}\left(T_{\text {noct }}-20\right)
\end{aligned}
$$

$V_{m p}$ : Voltage at the maximum power point, at the reference temperature $(\mathrm{V})$
$I_{m p}:$ Current at maximum power point, at the reference temperature $(\mathrm{A})$

$\mathrm{V}$ : Voltage at the point of maximum power, at operating temperature $(\mathrm{V})$

I: Current at maximum power point, at operating temperature (A)

$T_{c}$ : Operating temperature of the cell $\left({ }^{\circ} \mathrm{C}\right)$

$T_{0}$ : Reference temperature $\left({ }^{\circ} \mathrm{C}\right)$

$T_{\text {noct }}$ : Nominal operating temperature of the cell $\left({ }^{\circ} \mathrm{C}\right)$

$T_{a}$ : Ambient temperature $\left({ }^{\circ} \mathrm{C}\right)$

$\mu_{v}$ : Temperature coefficient of the open circuit voltage $\left(\mathrm{V} .{ }^{\circ} \mathrm{C}^{-1}\right)$

$\mu_{I}$ : Temperature coefficient of the short-circuit current (A. ${ }^{\circ} C^{-1}$ )

$G_{0}:$ Reference solar radiation (W. $m^{-2}$ )

G: Solar radiation of operation (W. $m^{-2}$ )

\subsection{Model 2}

In the 2000s, Jones and Underwood proposed this model to calculate the maximum electrical power available at the output terminal of a photovoltaic collector (Helali 2012).

$P_{2}=F F\left(I_{c c} \times \frac{G}{G_{0}}\right) \times\left(V_{c o} \times \frac{\ln \left(K_{1} G\right)}{\ln \left(K_{1} G_{0}\right)} \times \frac{T_{0}}{T_{c}}\right)$

$\mathrm{FF}$ is the form factor and is calculated by equation (6).

$$
F F=\frac{V_{m p} I_{m p}}{V_{c o} I_{c c}}
$$

The constant $K_{1}$ is

$$
K_{1}=\frac{I_{c c}}{G_{0}}
$$

With

$V_{c o}$ : The open circuit voltage $(\mathrm{V})$

$I_{c c}:$ The short-circuit current (A)

\subsection{Model 3}

This model is calculated by equation (8). It was developed and experimentally validated by $\mathrm{Lu}$ Lin in 2004 (Belhadj et al., 2010):

$$
P_{3}=(a \times G+b) \times T_{c}+c \times G+d
$$

$a=0.0002, b=0.0004, c=0.1007, d=0.1018$

\subsection{Model 4}

The power produced by a photovoltaic array is estimated from the data of the overall irradiation on an inclined plane, the ambient temperature and the data of the manufacturer of the photovoltaic module used (Diaf et al. 2007), (Doctorale Francophone Specialite and Lazarov Vladimir 2011):

$$
\begin{aligned}
P_{4}=\eta_{\text {ref }} \times[1- & \left.\gamma \times\left(T_{C}-T_{0}\right)+\lambda \times \log \left(\frac{G}{G_{0}}\right)\right] \times N \\
& \times G \times S
\end{aligned}
$$


$\eta_{\text {ref }}$ : Resistance efficiency of the modules making up the photovoltaic field under standard conditions $\left(T_{0}=25^{\circ} \mathrm{C}\right.$, $G_{0}=1000 \mathrm{~W} \cdot \mathrm{m}^{-2}$ ).

$\lambda$ : The coefficient of solar illumination, it is equal to 0.12 for a monocrystalline silicon module.

$\gamma$ : The coefficient of the temperature, it is comprised between 0.004 and 0.006 .

$\mathrm{N}$ : number of photovoltaic panels

S: surface of the photovoltaic module

\subsection{Choice of model}

To make the choice of the power available at the output of the PV panel terminal, we compared the powers available by each model found by referring to the power of the PV panel given by the manufacturer and this power is equal to $235 \mathrm{Wc}$. To do this work, the characteristics of the PV panel are given, then we wrote a computer program under matlab/script.

\section{a- PV Panel characteristics}

The photovoltaic PV panel used is the PV-GUIDEnR model consisting of 60 monocrystalline cells connected in series.

Table 1. PV Panel characteristics

\begin{tabular}{|l|l|}
\hline$P_{m p}(\mathrm{Wc})$ & 235 \\
\hline$\eta_{r e f}(\%)$ & 14.5 \\
\hline $\mathrm{FF}$ & 0.752 \\
\hline$V_{m p}(\mathrm{~V})$ & 29.5 \\
\hline$I_{m p}(\mathrm{~A})$ & 7.97 \\
\hline$\mu_{v}\left(V \cdot C^{-1}\right)$ & -0.356 \\
\hline$\mu_{I}\left(A \cdot C^{-1}\right)$ & 0.062 \\
\hline$V_{o c}(\mathrm{~V})$ & 36.9 \\
\hline$I_{c c}(\mathrm{~A})$ & 8.47 \\
\hline $\mathrm{S}\left(m^{2}\right)$ & 1.6236 \\
\hline$T_{\text {noct }}\left({ }^{\circ} \mathrm{C}\right)$ & 49 \\
\hline
\end{tabular}

\section{b- Model parameters}

To obtain the powers calculated using the different models and given in Table 2, we wrote a program under matlab when the radiation varies and the temperature of the cell being known parameters. When the radiation is $900 \mathrm{~W} . \mathrm{m}^{-2}$, we note the power corresponding to each model when the cell temperature is equal to $320 \mathrm{~K}, 322 \mathrm{~K}$, and $324 \mathrm{~K}$. Table 2 shows that model 4 is closer to the reference power given by the PV panel manufacturer. So, model 4 is used in the rest of the study.
Tableau 2. Comparison of the power available in each model in relation to the power of the PV panel given by the manufacturer

\begin{tabular}{|c|c|c|c|c|}
\hline $\begin{array}{l}\text { Maximum p } \\
\text { panel } 235 \mathrm{~W}\end{array}$ & wer give & $y$ the $c$ & structor & the PV \\
\hline $\begin{array}{l}\text { Cell } \\
\text { temperature }\end{array}$ & $\begin{array}{l}\text { Maximu } \\
\text { model i }\end{array}$ & $\begin{array}{l}\text { power } \\
W)\end{array}$ & available & for each \\
\hline (K) & Model1 & Model2 & Model3 & Model4 \\
\hline 320 & 182 & 187,3 & 33,01 & 203,2 \\
\hline 322 & 178,4 & 186,2 & 32,65 & 201,5 \\
\hline 324 & 174,6 & 185 & 32,29 & 189,8 \\
\hline
\end{tabular}

\subsection{Global radiation modeling on a given plane}

To calculate the global radiation $\mathrm{G}$, we use the model given by (Yaïche and Bekkouche 2010), and (Moummi et al. 2006). Its expression is given by equation (10).

$$
\begin{aligned}
G_{k}=S_{h} \times R_{k}+ & d_{h} \times\left(\frac{1+\cos \left(\beta_{k}\right)}{2}\right)+\rho_{0} \times\left(S_{h}+d_{h}\right) \\
& \times\left(\frac{1-\cos \left(\beta_{k}\right)}{2}\right)(10)
\end{aligned}
$$

With

$d_{h}$ : The irradiation diffuses on a horizontal plane. $\left(W \cdot m^{-2}\right)$.

$S_{h}$ : Direct irradiation on a horizontal plane $\left(W \cdot m^{-2}\right)$.

They are calculated according to equations (11) and (12).

$$
\begin{gathered}
d_{h}=125 \times(\sinh )^{0.4}(11) \\
S_{h}=1230 \times \sin (h) \times \exp \left(\frac{-1}{4 \times \sin (h+2)}\right)
\end{gathered}
$$

If the PV panel is fixed $\beta_{k}=\beta_{0}=15^{\circ}$ and the tilt factor $R_{k}=R_{f}$ is given by the equation (13)

$R_{f}$

$=\frac{\cos \left(\varphi_{0}-\beta_{0}\right) \cdot \cos \left(\delta_{0}\right) \cdot \cos \left(A_{h}\right)+\sin \left(\varphi_{0}-\beta_{0}\right) \cdot \sin \left(\delta_{0}\right)}{\cos \left(\varphi_{0}\right) \cdot \cos \left(\delta_{0}\right) \cdot \cos \left(A_{h}\right)+\sin \left(\varphi_{0}\right) \cdot \sin \left(\delta_{0}\right)}$

For the case of a movable PV panel with one axis, the angle $\beta_{k}=\beta$ and $R_{k}=R_{m}$ are calculated (Mabrouk 2017) by relations (14) and (15).

$$
\beta=\tan ^{-1}\left[\frac{\sin \left(A_{0}+A_{s}\right)}{\tan (h)}\right]
$$

$$
\begin{aligned}
& R_{m} \\
& =\frac{\left[1-\left(\cos (h) \cdot \cos \left(A_{0}+A_{s}\right)\right)^{2}\right]^{0.5}}{\cos \left(\varphi_{0}\right) \cdot \cos \left(\delta_{0}\right) \cdot \cos \left(A_{h}\right)+\sin \left(\varphi_{0}\right) \cdot \sin \left(\delta_{0}\right)} \\
& A_{S} \\
& =\frac{\cos \left(\varphi_{0}\right) \cdot \cos \left(\delta_{0}\right) \cdot \cos \left(A_{h}\right)-\cos \left(\varphi_{0}\right) \cdot \sin \left(\delta_{0}\right)}{\cosh }
\end{aligned}
$$

$\rho_{0}:$ The albedo of the soil

$h$ : The height of the sun (degree)

$\varphi_{0}:$ The latitude of the place (degree)

$\delta_{0}$ : The declination of the sun (degree) 
$A_{h}$ : The hourly angle of the sun (degrees)

$A_{s}$ : The azimuth of the sun (degree)

$A_{0}$ : Orientation of the plan (degree)

\subsection{Calculation of the parameters related to the sun trajectory}

The relative motion of the sun with respect to the earth is composed on the one hand of an annual motion during which the earth moves in an elliptical orbit almost circular and on the other hand of a rotational motion of the earth on itself with a periodicity equal to one day (Beckers and Beckers, 2010). Thus, on a site which is located at a point on the surface of the Earth, we need to know the declination, the latitude, the longitude, the height of the sun, the azimuth of the sun, the hour angle, the zenith angle and possibly the orientation of the plane of the PV module at this location (Zaatri, 2009; Sarr, Kebe, and Ghennioui, 2020 ; Rezoug and Chenni, 2018 ; Mohamed and Abdellah, 2017 ; Rezoug, 2011).

The declination is calculated by equation (17):

$$
\delta_{0}=24.45 \times \sin \left(\frac{360}{365}(J-81)\right)
$$

The height of the sun is given by equation (18)

$$
\begin{array}{r}
\sin (h)=\cos \left(\varphi_{0}\right) \cdot \cos \left(\delta_{0}\right) \cdot \cos \left(A_{h}\right) \\
+\sin \left(\varphi_{0}\right) \cdot \sin \left(\delta_{0}\right)
\end{array}
$$

Calculation of the hour angle $A_{h}$

$$
\begin{gathered}
A_{h}=15 \times(T S V-12) \quad(20) \\
T S V=T L-\left(T U-\frac{L_{0}}{15}\right)+\frac{\delta t}{60} \quad(20) \\
X=\frac{360}{365}(J-81) \quad(21) \\
\delta t=9.87 \times \sin (X)-7.35 \times \cos (X)-1.5 \\
\times \sin (X)(22)
\end{gathered}
$$

With

TSV: True Solar Time

TU: Universal Time (this is the time different from the Greenwich meridian).

TL: Legal Time (time given by a watch)

$\delta t$ : Correction of the equation of time.

$L_{0}$ : Longitude of the place.

\section{RESULTS AND DISCUSSION}

During the day of $28 / 05 / 2020$ in Dakar, under the latitudes of $14.7^{\circ} \mathrm{N}$, longitude $17.4^{\circ} \mathrm{W}$ and solar declination $21.6^{\circ}$, with a sky of average clarity and an ambient temperature of $27^{\circ} \mathrm{C}$.

The organization chart is presented in figure 1.

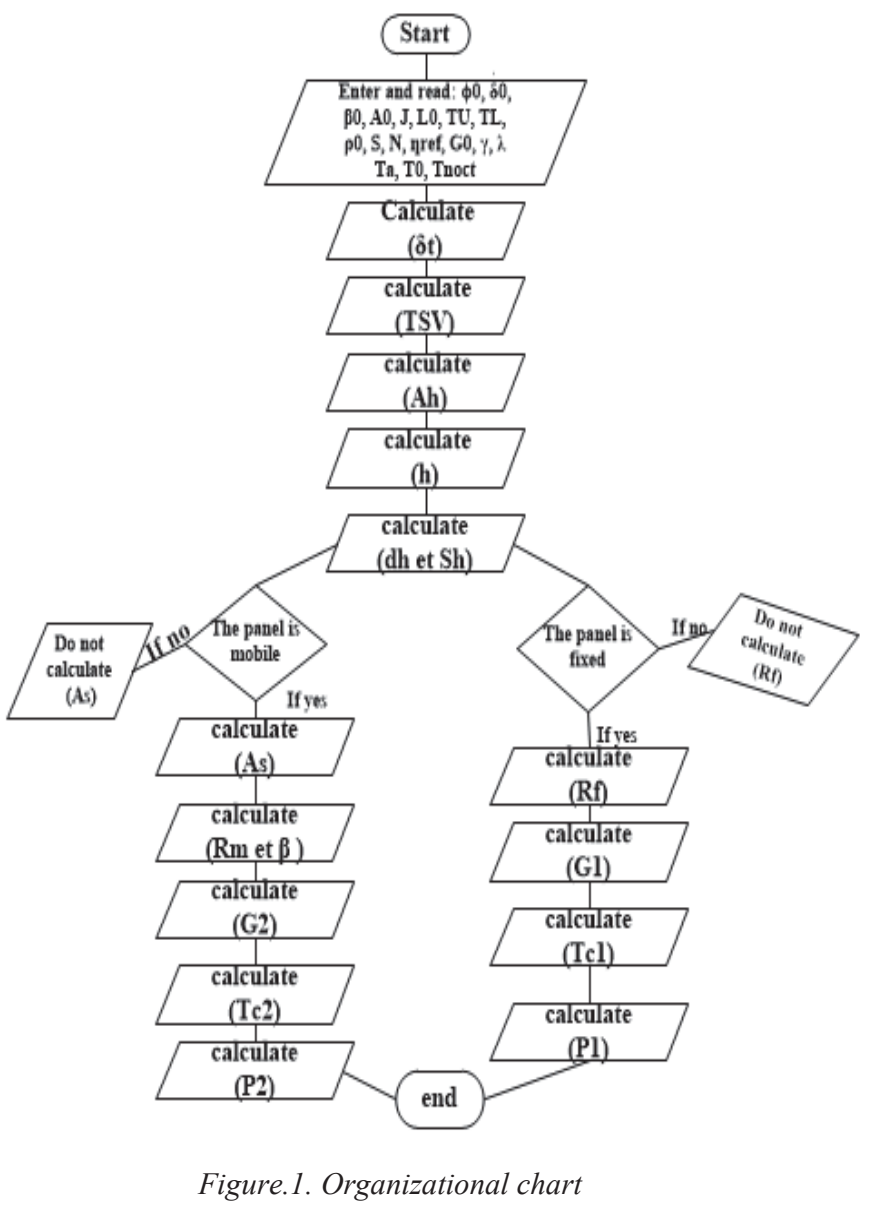

\subsection{Results obtained}

\section{a- Power output curves for one day}

The results in Figure 2 show the power output for the mobile PV panel and for the fixed PV panel.

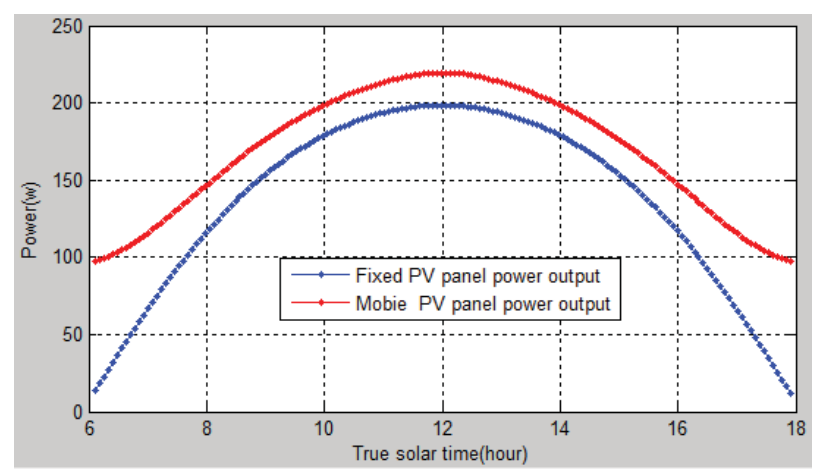

Figure.2. Comparison curve between the production power of the two systems during one day

\section{b- Average power curves produced per day for one month}

The curves in figure 3 represent the results obtained when both systems are in operation for one month. 


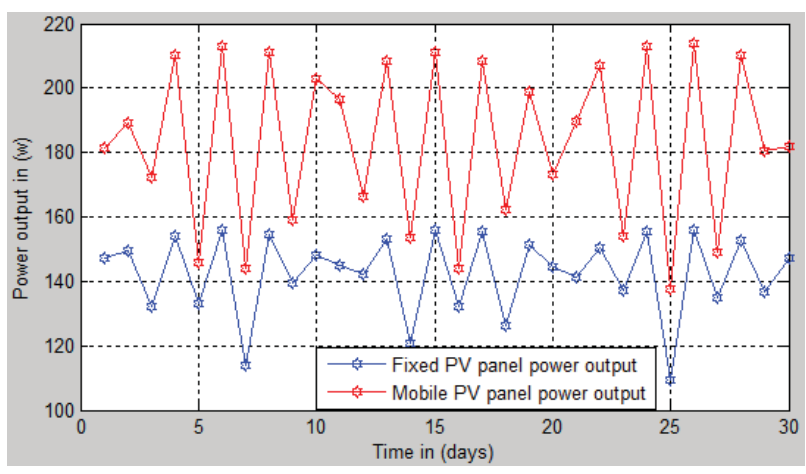

Figure.3. Average daily power produced by the two systems during one month

\subsection{Discussion}

Figures (2) and (3) shows that the curves evolve in the same way. For figure (2), both curves evolve in an increasing way from $6 \mathrm{~h}$ to $12 \mathrm{~h}$ (True Solar Time), and from $12 \mathrm{~h}$ to $18 \mathrm{~h}$, both curves evolve in a decreasing way. For figure (3) the evolution of the two curves is identical but not uniform, which allows us to say that the solar radiation is not constant, it varies according to the day. According to figure 2 we can understand that the more the day advances the more the power output of the two PV panels is important until solar noon, but after solar noon the production decreases again. So what allows to say that the maximum production of the PV panels depends strongly on the position of the sun of the sun? The observation made on the two figures shows that the power output of the mobile PV panel is more important than that of the fixed PV panel. Then this is justified by the fact that when the mobile PV panel follows the sun, the solar rays are projected perpendicular to its surface. In this case, the mobile PV panel extracts the maximum of solar energy unlike the fixed PV panel which receives the solar rays in a perpendicular way only at a single moment of the day.

This work is so important that the results of figure (2) obtained during the day reveal that the use of mobile PV panel improves the power output of the fixed panel by more than 10 to $26 \%$ depending on the time of day, i.e. an average percentage of $17 \%$ during the day. The results of figure (3) obtained during the month show that the use of mobile panel improved the power output the fixed PV panel by 10 to $38 \%$ depending on the day. The results of this study are important which reveals the need for the design of solar trackers.

\section{CONCLUSION}

The results of this work are very important and allow us to understand the variation of the power output of the mobile PV panel compared to the fixed panel.

In summary, the mobile PV panel allows to optimize the production of power from $10 \%$ to $38 \%$ compared to the fixed PV panel. In this study the method used is the theoretical method that consists in looking for mathematical models and choosing one model to be applied to each PV panel. This choice is based on the power output. In this work we recognize what is not yet done, that is to say, the experimental study to finally be able to see or compare experience and theory. So after obtaining these results we are interested in knowing the maximum step of variation when the mobile PV panel moves and if it is fixed. To evaluate the energy consumed by the motor of the mobile PV panel will it be profitable compared to the production of the fixed panel?

\section{References}

Aidara, Mohamed Cherif, Mamadou Lamine Ndiaye, and Willy Magloire Nkounga. 2018. "Correlation between dirt on the photovoltaic module surface and climatic parameters in the Dakar region, Senegal." Pp. 517-21 in 2018 7th International Conference on Renewable Energy Research and Applications (ICRERA). IEEE. Retrieved November 17, 2020 (https://ieeexplore.ieee.org/document/8566807/).

Beckers, Benoit and Pierre, Beckers. 2010. Comment calculer la déclinaison du soleil. Retrieved November 17,2020 http://www.heliodon.net/downloads/Beckers_2010_He lio_007_fr.pdf.

Belhadj, M. et al. 2010. Estimation de la puissance maximale produite par un générateur photovoltaïque.

https:/www.researchgate.net/publication/257207609_Es timation_de_la_puissance_maximale_produite_par_un generateur_photovoltaique

Bidart, A. and L. Dubois. 2003. "Les énergies fossiles et renouvelables.” Retrieved September 8, 2020 (http://pe12evreux.free.fr/fichiers/fondation_polaire/m edias/pdfs/dossier4.pdf).

Cisse, Oumar et al., 2018. "Water and Energy Management based on Fuzzy Logic and Linear Programming for a Photovoltaic/ Wind/Battery Pumping System in Rural Environment". 7th International Conference on Renewable Energy Research and Applications (ICRERA). pp 1115-1120 DOI: 10.1109/ICRERA.2018.8566980

Diaf, Said et al. 2007. "A methodology for optimal sizing of autonomous hybrid PV / wind system" Energy policy 35, 5708-5718.

Ludmil Stoyanov. Étude de différentes structures de systèmes hybrides à sources d'énergie renouvelables. Énergie électrique. Université Pascal Paoli, 2011. Français. tel-00653412. Retrieved September 8, 2020 (https://tel.archives-ouvertes.fr/tel-00653412/).

GUEYE, Samba. 2014. "Conception d'un régulateur solaire avec commande MPPT". Sciences Appliquées et de 1'Ingénieur, [S.1.], v. 1, n. 2, p. 104-108.

Retrieved November 17, 2020 http://publication.lecames.org/index.php/ing/article/vie $\mathrm{w} / 205$.

Helali, K. 2012. "Modelisation d'une Cellule photovoltaique: étude comparative." Retrieved November 17, 2020

(https://www.academia.edu/download/36893015/mem oire-18.pdf). 
Mabrouk, Mohamed Tahar. 2017. "Production optimale d'énergie pour une communauté à petite échelle : application à l'optimisation d'une centrale solaire hybride produisant électricité et chaleur. HAL Id : Tel01630224 .

Boujenane, Samira, 2016. "Tracker solaire à deux axes". Mémoire de Master. Université Sidi Mohamed Ben Abdellah https://www.memoireonline.com/03/20/11730/m_Trac ker-solaire-a-deux-axes $0 . h t m l$

Moummi, A.et al. 2006. Estimation du rayonnement solaire par deux approches semi empiriques dans le site de Biskra. Retrieved November 17, 2020 https://www.researchgate.net/publication/264781835

Ndiaye, Mouhamadou Falilou et al.. 2018. Short-Term forecasting for solar irradiation based on the multilayer neural network with the levenberg-marquardt algorithm and meteorological data : application to the gandon site in Senegal. 7th International Conference on Renewable Energy Research and Applications (ICRERA). ISBN: 978-1-5386-3/18 - pp 869-874

Rezoug, M.r. and Zaatri, A. "Calcul de la durée optimale d'activité d'un module photovoltaïque en fonction de l'endroit". Revue des Energies Renouvelables, Vol 14, № 1, Pp 163-169.

Sarr, A. et al. 2020. "Comparative approach for global solar estimation in four typical senegalese climatic zones." pp. 1-6 in 2020 5th international conference on renewable energies for developing countries, REDEC 2020. Institute of Electrical and Electronics Engineers Inc. Retrieved November 17, 2020 https://ieeexplore.ieee.org/document/9163881/

Yaïche, M. and S. M. Bekkouche. 2010. "Estimation du rayonnement solaire global en algérie pour différents types de ciel. Revue des energies renouvelables, Vol. 13, N4, Pp. $683-695$.

Zaatri, R. and Rezoug A. 2009. "Optimisation du rendement d'un système photovoltaïque par poursuite du soleil." Revue des Energies Renouvelables Vol. 12 $\mathrm{N}^{\circ} 2,299-306$. 


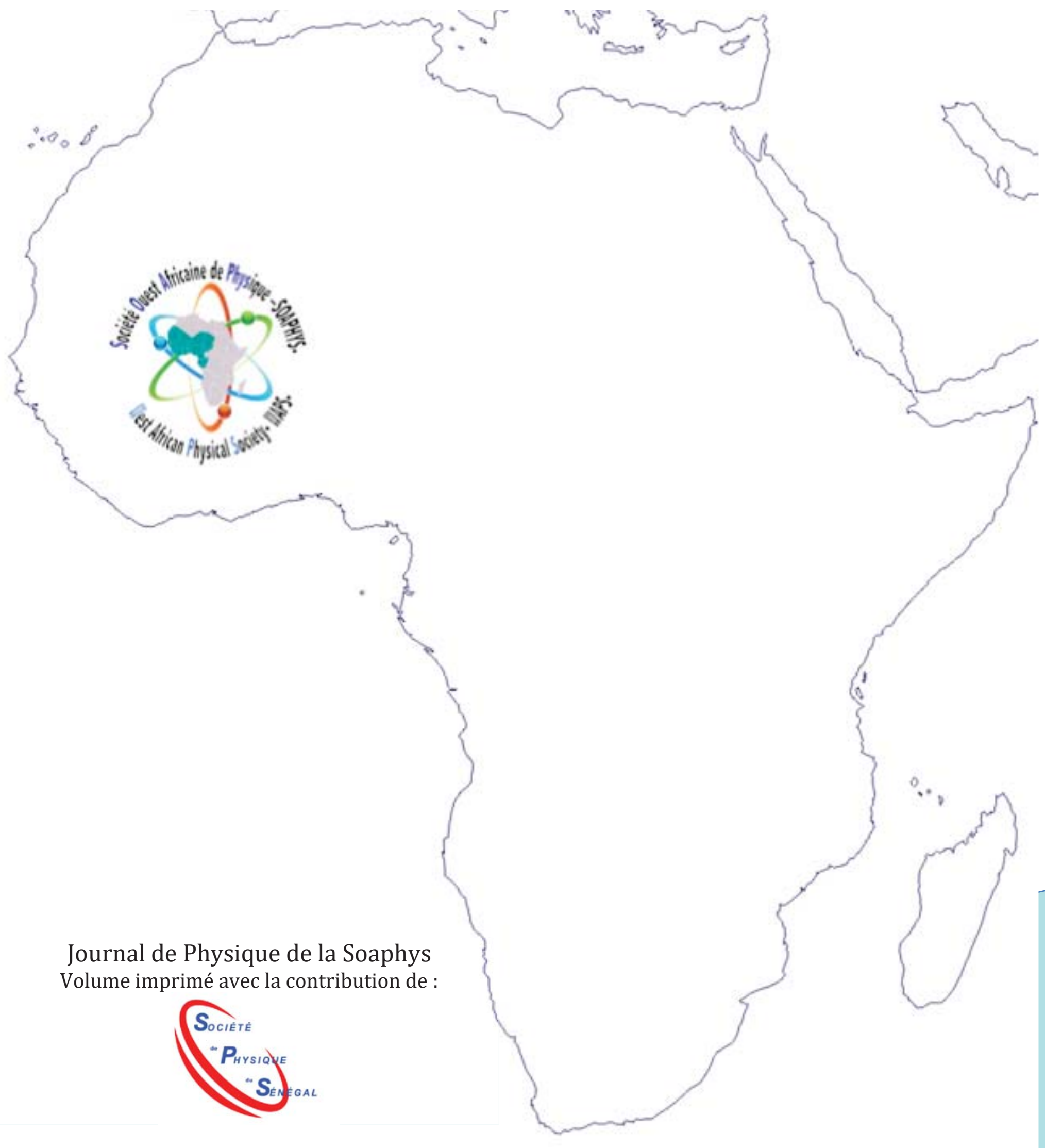

